Supporting Information:

\title{
Ion Coordinating Sensitizer for High Efficiency Mesoscopic Dye-Sensitized Solar Cells: Influence of Lithium Ions on the Photovoltaic Performance of Liquid and Solid-State Cells
}

Daibin Kuang, Cedric Klein, Henry J. Snaith, Jacques-E Moser, Robin Humphry-Baker, Pascal Comte, Shaik. M. Zakeeruddin, and Michael Grätzel

Laboratory for Photonics and Interfaces, Institute of Chemical Sciences and

Engineering, Ecole Polytechnique Fédérale de Lausanne, 1015 Lausanne, Switzerland 


\section{Synthesis of 4,4'-bis [(triethyleneglycolmethylether) methylether]-2,2'-bipyridine.}

$\mathrm{NaH}(55-65 \%$ dispersion in mineral oil, $510 \mathrm{mg}, \approx 11.7 \mathrm{mmol})$ was added to a solution of triethylene glycol monomethyl ether $(1.44 \mathrm{~g}, 8.8 \mathrm{mmol})$ in dry THF (50 ml) and the resulting mixture was stirred 30 minutes at room temperature under nitrogen. 4,4'-dibromomethyl-2,2'-bipyridine (1 g, $2.92 \mathrm{mmol}$ ) was then added in one portion and the solution was refluxed for 6 hours. After being cooled to room temperature, water $(5 \mathrm{ml})$ was drop wise added and THF was evaporated in vacuum. Water (100 ml) was added and extracted with $\mathrm{CH}_{2} \mathrm{Cl}_{2}(3 \times 100 \mathrm{ml})$. The combined organic fractions were washed with water $(50 \mathrm{ml})$, dried over $\mathrm{Na}_{2} \mathrm{SO}_{4}$ and evaporated to dryness. The oily residue was then purified by column chromatography $\left(\mathrm{SiO}_{2}, \mathrm{EtOAc} / \mathrm{MeOH}: 8 / 2\right)$ to afford $1.2 \mathrm{~g}(81 \%)$ of the titled compound as a colorless oil. ${ }^{1} \mathrm{H}$ NMR $\left(200 \mathrm{MHz}, 25^{\circ} \mathrm{C}\right.$, $\left.\mathrm{CDCl}_{3}\right) \delta 3.38(\mathrm{~s}, 6 \mathrm{H}), 3.5-3.8(\mathrm{~m}, 24 \mathrm{H}), 4.69(\mathrm{~s}, 4 \mathrm{H}), 7.39(\mathrm{~d}, J=5 \mathrm{~Hz}, 2 \mathrm{H}), 8.35(\mathrm{~s}$, $2 \mathrm{H}), 8.65(\mathrm{~d}, J=5 \mathrm{~Hz}, 2 \mathrm{H}) .{ }^{13} \mathrm{C} \mathrm{NMR}\left(50 \mathrm{MHz}, 25^{\circ} \mathrm{C}, \mathrm{CDCl}_{3}\right) \delta 59.0,70.2,70.3,70.5$, 70.6, 70.7, 71.7, 71.9, 119.4, 122.0, 149.0, 149.2, 155.7.

\section{Synthesis of NaRu(4-carboxylic acid-4'-carboxylate)(4,4'- bis [(triethyleneglycol methylether) methylether J-2,2'-bipyridine $)(\mathrm{NCS})_{2}(\mathrm{~K} 51)$}

$\mathrm{RuCl}_{2}(p$-cymene) and 4,4'- bis[(triethyleneglycolmethylether) methylether]-2,2'bipyridine were dissolved in DMF $(500 \mathrm{ml})$ in 1: 2 molar ratio. The reaction mixture was heated to $60{ }^{\circ} \mathrm{C}$ under nitrogen for $4 \mathrm{~h}$ under constant stirring. Subsequently, one equivalent of 4,4'-dicarboxylic acid-2,2-bipyridine was added to this reaction flask and the reaction mixture was refluxed at $140{ }^{\circ} \mathrm{C}$ for $4 \mathrm{~h}$. Finally, an excess of $\mathrm{NH}_{4} \mathrm{NCS}$ was added to the reaction mixture and the reflux continued for another $4 \mathrm{~h}$. The reaction mixture was cooled down to room temperature and the solvent was removed by using a rotary evaporator under vacuum. Water was added to the flask and the insoluble solid was collected on a sintered glass crucible by suction filtration. The solid was washed with distilled water and diethyl ether, and then dried under vacuum. The crude complex was further purified on a Sephadex LH-20 column with methanol as eluent. The collected main band was evaporated to dryness and dissolved in water then slowly titrated with dilute nitric acid solution to $\mathrm{pH}$ 4.8. The precipitate was collected on a sintered glass crucible by suction filtration and dried. ${ }^{1} \mathrm{H}$ NMR $\left(\delta_{\mathrm{H}} / \mathrm{ppm}\right.$ in $\left.\mathrm{CD}_{3} \mathrm{OD} / \mathrm{NaOH}\right): 9.55(\mathrm{~d}, 1 \mathrm{H}), 9.40(\mathrm{~d}, 1 \mathrm{H}), 9.05(\mathrm{~s}, 1 \mathrm{H}), 8.85(\mathrm{~s}, 1 \mathrm{H}), 8.60(\mathrm{~s}, 1 \mathrm{H}), 8.40$ $(\mathrm{s}, 1 \mathrm{H}), 8.25(\mathrm{~d}, 1 \mathrm{H}), 7.85(\mathrm{~d}, 1 \mathrm{H}), 7.70(\mathrm{~d}, 1 \mathrm{H}), 7.55(\mathrm{dd}, 2 \mathrm{H}), 7.20(\mathrm{~d}, 1 \mathrm{H}), 5.05(\mathrm{~s}$, 
$2 \mathrm{H}), 4.65(\mathrm{~s}, 2 \mathrm{H}), 3.9-3.5(\mathrm{~m}, 24 \mathrm{H}), 3.30(\mathrm{~s}, 6 \mathrm{H})$. Analytical calculation for

$\mathrm{NaRuC}_{40} \mathrm{H}_{47} \mathrm{~N}_{6} \mathrm{O}_{12} \mathrm{~S}_{2} 2 \mathrm{H}_{2} \mathrm{O}: \mathrm{C}, 46.7 ; \mathrm{H}, 5.0 ; \mathrm{N}, 8.20 \%$. Found; C, 46.1; H, 5.0; N, 8.5\%.

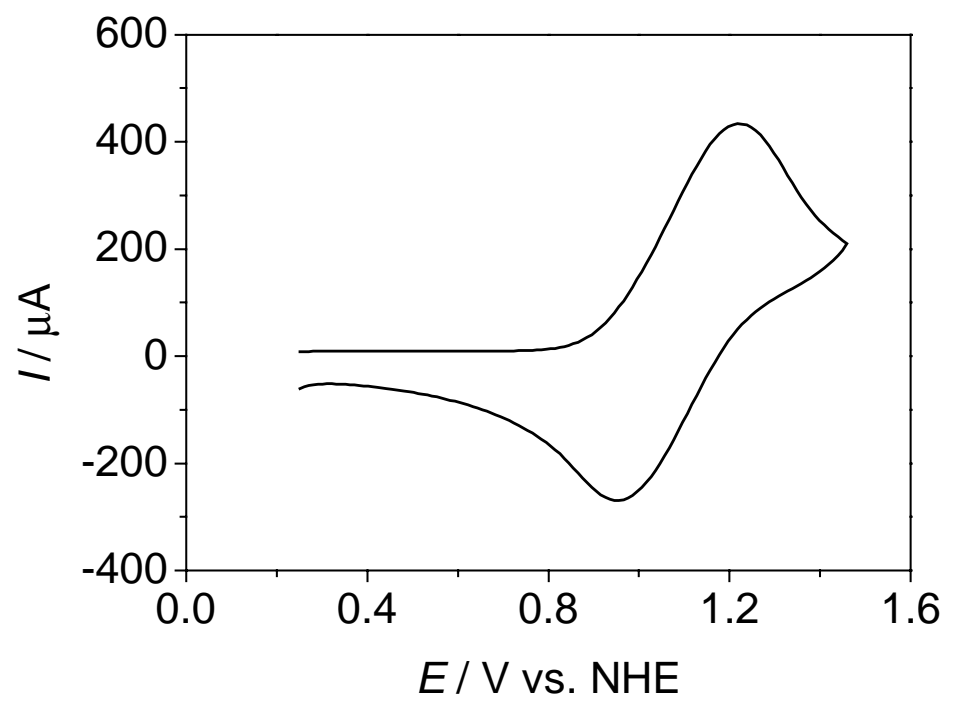

Figure S1 Cyclic voltammogram curve of K51 dye adsorbed on $6 \mu \mathrm{m}$ thick mesoscopic transparent $\mathrm{TiO}_{2}$ (particle size $\sim 20 \mathrm{~nm}$ ) electrode. The electrolyte is 0.1 $\mathrm{M}$ tetrabutylammonium perchlorate in acetonitrile. $\mathrm{Ag} / \mathrm{AgI}$ used as the reference electrode and Pt foil as the counter electrode. Scan rate $100 \mathrm{mV} / \mathrm{s}$. 


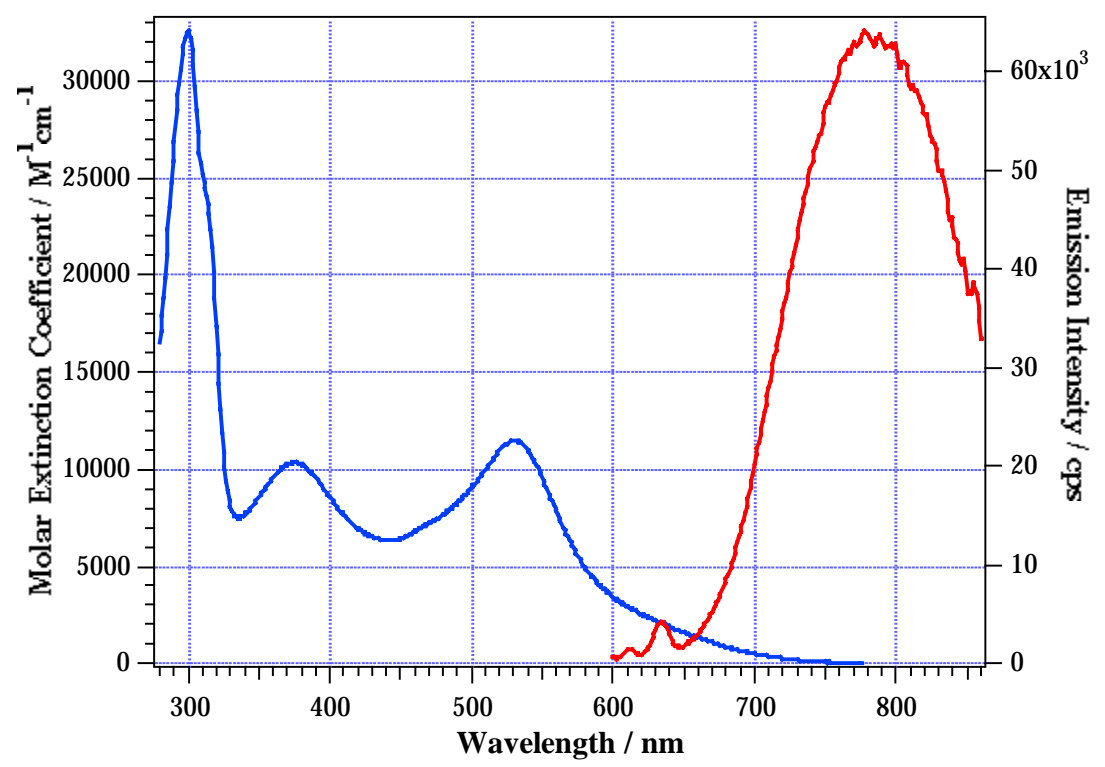

Figure S2 Optical absorption and emission spectra of the K51 dye in DMF.

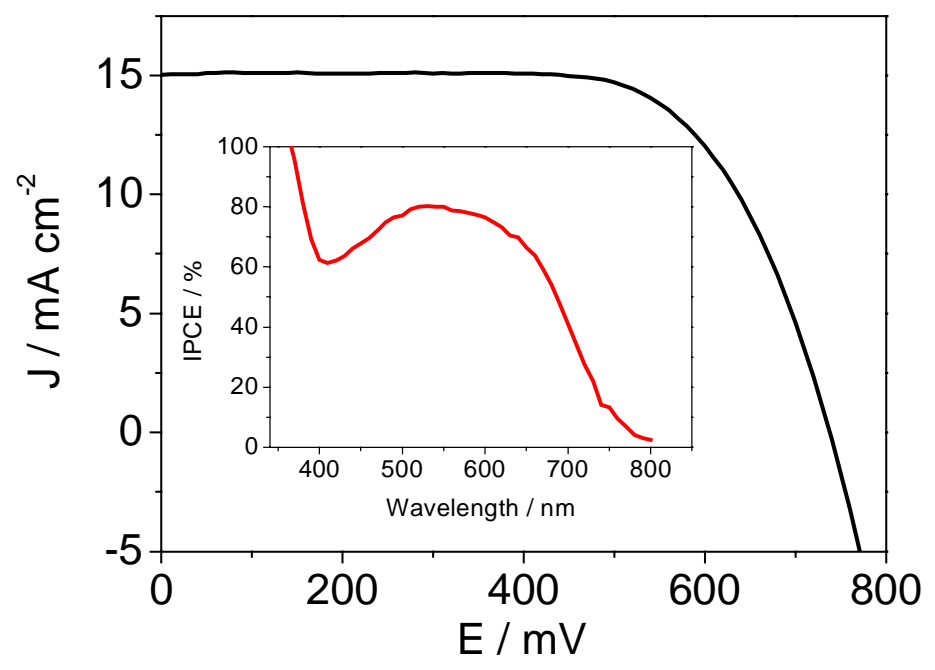

Figure S3 Photocurrent density-voltage curve for a DSC comprising K51 dye with electrolyte A under simulated AM 1.5 solar illumination at $100 \mathrm{mWcm}^{-2}$. The cell area was defined by a mask of $0.158 \mathrm{~cm}^{2}$. Insert: Photocurrent action spectra of the same DSC device. 